auto-immunity. The presence of large aggregates of pyroninophilic cells in the spleen and lymph nodes in our neonatally thymectomized animals, and similar observa. tions in rats by Waksman et al.12, also suggest this possibility, although as yet we have no proof of immune competence of these cells. Whether auto-immunity plays a part in the pathogenesis of radiation-induced lesions of the kidney remains to be demonstrated by definitive immunological examinations. The present findings warrant further investigations of this possibility.

We thank Dr. H. I. Kohn for his help in the experiment. This work was supported by the U.S. Atomic Energy Commission.

Paul H. Guttman DoNald W. BaIley

Cancer Research Institute,

University of California,

San Francisco Medical Center.

${ }^{1}$ Guttman, P. H., and Kohn, H. I., Amer. J. Path., 37, 293 (1960).

${ }^{2}$ Guttman, P. H. (unpublished results).

${ }^{3}$ Movat, H. Z., MeGregor, D. D., and Steiner, J. W., Amer. J. Path., 36, 306 (1961).

${ }^{4}$ Bailey, D., and Usama, B., Transp. Bull., 7, 424 (1960).

${ }^{5}$ Rinehart, J. F., and Abdul-Haj, S. K., Amer. Med. Assoc. Arch. Path., 52 189 (1951).

- Guttman, P. H., and Kohn, H. I., Amer. J. Path., 43, 809 (1963).

2 DeVries, M. J., Van Putten, I. M., Balner, H., and Van Bekkum, D. W. Rev. Franc. Etudes Clin. Biol., 9, 381 (1964).

8 Papermaster, B. W., Dalmasso, A. P., Martinez, C., and Good, R. A. Proc. Soc. Exp. Biol. and Med., 8, 41 (1962).

' Jankovic, B. D., Waksman, B. H., and Arnason, B. G., J. Exp. Med., 116, $159(1962)$

10 Miller, J. F. A. P., Brit. Med. J., ii, 459 (1963).

${ }^{11}$ Good, R. A. (personal communication). ${ }^{12}$ Waksman, B. H., Arnason, B. G., and Jankovic, B. D., J. Exp. Med., 116,
187 (1962).

\section{Antigenic Properties of Burnt Skin}

ON surveying the literature pertaining to this subject, it was found that workers in the Eastern European countries $^{1}$ maintain that the use of convalescent serum in burnt patients is of considerable therapeutic value due to a hypothetical antibody to burnt skin ${ }^{2}$. Workers in the Western world $d^{3-7}$ in the same field have been unable as yet to prove the existence of such an immunological mechanism and have claimed that any antibody demonstrated so far has been one produced by bacteria, thus not specific to burnt tissue.

Table 1. ANTIGEN-ANTIBODY REACTIONS WITH SERA OF RABBITS IMMUNIZED WITH VARIOUS PORTIONS OF RABBIT SKIN, BY DIFFERENT IMMUNOLOGIC

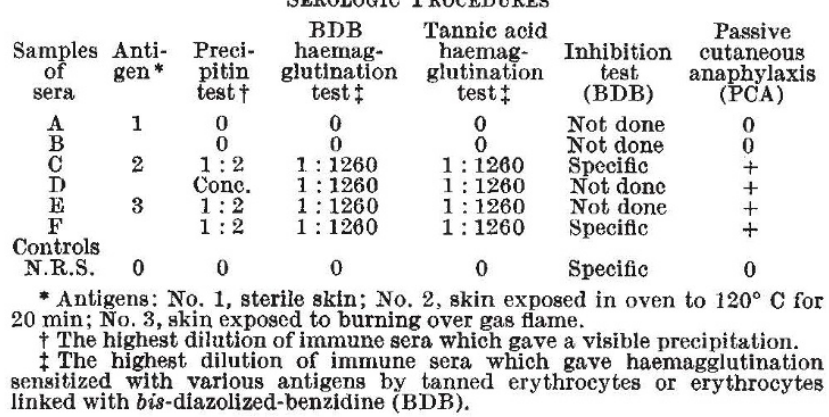

A pilot experiment on this subject was conducted, using several immunological procedures. Three groups of rabbits were immunized with antigens, prepared from: (1) a portion of sterile skin from a freshly killed rabbit; (2) a portion of skin of the same rabbit after having been exposed to a temperature of $120^{\circ} \mathrm{C}$ in an oven for $20 \mathrm{~min}$; (3) a portion of skin of the same rabbit, after having been exposed to burning over a gas flame. Six rabbits were immunized; $A$ and $B$, with antigen $1 ; C$ and $D$, with antigen $2 ; E$ and $F$, with antigen 3 .

The antigens were prepared by homogenizing the three portions of skin in a Waring blender, with subsequent extraction in normal saline. The antigens were defatted with ether during $24 \mathrm{~h}$. Sterility was confirmed by culture.

The sera obtained from the rabbits after repeated immunization for a period of about 6 weeks were studied by several methods, such as haemagglutination and haemagglutination inhibition tests (BDB and tannic acid method), precipitin tests, gel-diffusion and passive cutaneous anaphylaxis in the guinea-pig. The results are summarized in Tables 1 and 2 . These results show that burnt skin has antigenic properties, producing antibodies in rabbits, different from normal skin. It has to be pointed out that there are still considerable difficulties as to the reproducibility of the experiments, their crossreactivity among the various portions of the skin, etc. Although antibodies in rabbits have been produced from burnt skin, the specificity of these antibodies, and their relationship to human burns, has to be investigated in greater detail.

\section{S. ZVI Kantor \\ I. KAPLAN \\ Ester Gruenberg \\ S. GITTER}

Rogoff Modical Research Institute,

University of Tel-Aviv, and Beilinson Hospital, Petah Tikva, Israel.

${ }^{1}$ Feodorov, N. A., and Skurkovith, S. V., Kirurgia, 9, 48 (1955).

${ }^{2}$ Feodorov, N. A., Skurkovith, S. V., Freeman, V. T., and Muzichenka, A. P., Patholo
$(1959)$.

${ }^{3}$ Dobrokovsky, M., Dolezalova, J., and Pavlova, L., Research in Burns (Amer. Inst. of Biol. Sciences, Wash., D.C., Philadelphia, F. A. Davis Company, $1962)$.

${ }^{4}$ Newton, William T., Koichi Fuju, and Moyer, Carl A., Arch. Surg., 85, 912 (1962).

s Matter, P., Chambler, K., Bailey, B., Lewis, S., Blocker, T., and Blocker, V., Ann. Surg., 157, 725 (1963).

'Rosenthal, S. R., and Lewis, G. P., Univ. Illinois Annual Progress Report to ONR (1960).

"Cohn, J., of Queen Mary's Hospital, London (personal communication to Dr. Alexander Cohn, Israel Institute of Biol. Research, Ness Zionah).

\section{HISTOLOGY}

\section{Venous Output of Lymphocytes from the Thymus}

Following the extensive quantitative investigations of Kindred ${ }^{1,2}$ on the frequency of mitosis in different lymphatic organs, it has been known that intense lymphocytopoiesis occurs in the thymus. This observation has repeatedly been confirmed by other workers, using

Table 2. Cross-Reactions of Immune Sera with Various Skin Antigens

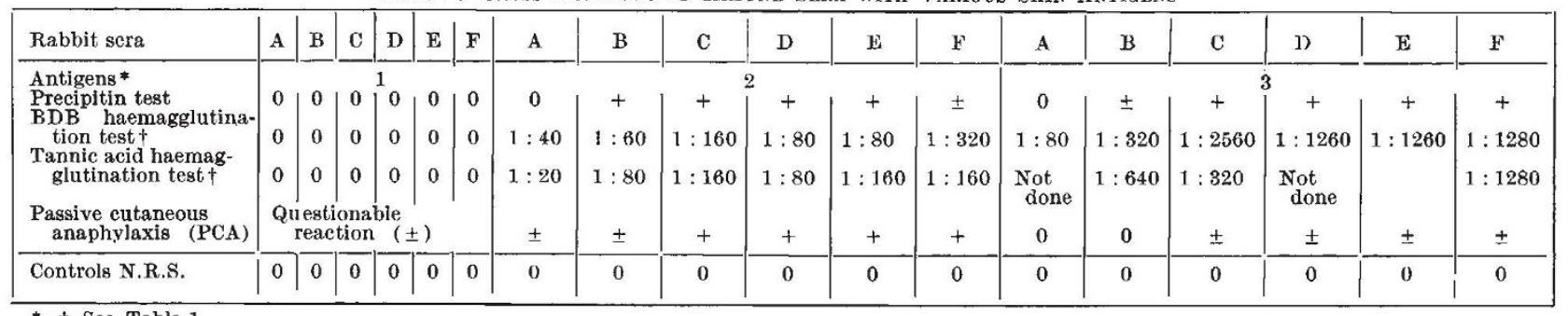

*, $\uparrow$, See Table 1 